\title{
Traditional ecological knowledge in conserving marine resources in Terengganu, Malaysia
}

\author{
WAN IZATUL ASMA WAN TALAAT ${ }^{1 \bullet}$, SYUHADA MD JUHARI ${ }^{1,}$, NORIZAN ESA ${ }^{3}$, SALASIAH CHE LAH ${ }^{2}$, \\ BADARUDDIN MOHAMAD ${ }^{4}$ \\ ${ }^{1}$ Institute of Oceanography and Environment, Universiti Malaysia Terengganu. 21030 Kuala Nerus, Terengganu, Malaysia.”email: wia@ umt.edu.my \\ ${ }^{2}$ School of Humanities, Universiti Sains Malaysia. 11800 Gelugor, Penang, Malaysia \\ ${ }^{3}$ School of Educational Studies, Universiti Sains Malaysia. 11800 Gelugor, Penang, Malaysia \\ ${ }^{4}$ School of Housing, Building and Planning, Universiti Sains Malaysia. 11800 Gelugor, Penang, Malaysia
}

Manuscript received: 18 November 2017. Revision accepted: 17 December 2017.

\begin{abstract}
Talaat WIAW, Md Juhari S, Esa N, Che Lah S, Mohamad M. 2018. Traditional ecological knowledge in conserving marine resources in Terengganu, Malaysia. Nusantara Bioscience 10: 6-11. Conserving marine resources to ensure its sustainable supply requires concerted effort by all the stakeholders including the local fishermen. The zoning of MPAs by the anvernment is a formal method of conserving marine resources where some efforts of conservation on the specified areas are de stra Currently, in the Terengganu waters, which sits in the southernmost part of the South China Sea, the only MPAs are tha 13 ands/ar zoned as marine parks amounting to $568.69 \mathrm{~km}^{2}$. Nonetheless, protecting or conserving marine resources cannot areas rrounding these marine parks alone. With $244 \mathrm{~km}$ coastline and fishing is inherently a major economic activity ne stan mo the Terengganu waters should be designated as MPAs or alternatively gazetted as ecologically sensitiy as. marine resources to ensure its sustainable supply, a concerted effort must be carried out by all the ders in ling communities, whose livelihood are directly impacted. As repositories of knowledge with regard to biodivers habita their seasonal fluctuations, the local communities must also be appreciated as resource users. The lom mermen's EK incruding familiarity with the use of sustainable fishing methods and practices are indeed pertinent for the s ainable supply o arine resources. This paper discusses the existing marine conservation efforts in Terengganu as well explore he pos lity of factoring in the local communities' local knowledge through collaborative management to enhance thes

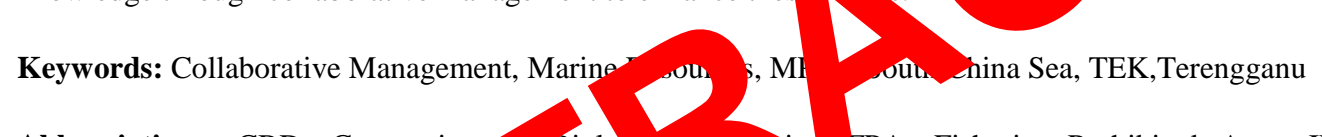

Abbreviations: CBD: Convention Biolo
\end{abstract} Conservation of Nature, MPAs:-Mune tected as, TEK: Traditional Ecological Knowledge

Marine are mportant to the livelihood of mankind es ially the coastal communities in Terengganu, ich is situated on the east coast of Peninsular Malaysia facing the South China Sea. Fishing has been the main source of income of the Terengganu coastal communities for generations. To conserve marine resources in order to ensure its sustainable supply, concerted effort must be carried out by all the stakeholders including the local fishermen, whose livelihood are directly impacted. It is a well-known fact that the use of sustainable fishing methods, along with the sustainable fishing practices, are pertinent in assuring the sustainable supply of marine resources (Islam et al. 2014).

The introduction and designation of MPAs by the government is a formal method of conserving marine resources. By designating an MPA, either as marine park islands or marine reserves, some efforts of conservation on the specified areas are demonstrated. The IUCN (Resolution 19.46 of the IUCN General Assembly 1994) provides the most commonly accepted definition of an MPA as; "Any area of the intertidal or subtidal terrain, together with its overlying water and associated flora, fauna, historical and cultural features, which has been reserved by law or other effective means to protect part or all of the enclosed environment." (Reaffirmed in Resolution 17.38 of the IUCN general assembly [1998]) (Kelleher 1999).

A broader term was introduced by the CBD to solve the uncertainty in classifying MPAs by introducing the marine and coastal protected area (MCPA) as; "Any defined area within or adjacent to the marine environment, together with its overlying water and associated flora, fauna, historical and cultural features, which has been reserved by legislation or other effective means, including custom, with the effect that its marine and/or coastal biodiversity enjoys a higher level of protection than its surroundings." (UNEPWCMC 2014)

MPAs have become an important tool to meet various biodiversity conservation efforts, fisheries management and social goals (Christie and White 2006). The objectives of establishing and gazetting MPAs are manifold with the main aim is to sustainably conserve marine resources. Amongst the objectives are to establish specific zones for preservation of the marine resources and also for the 
purpose of research and educational activities, preserve and protect of coral reef areas from the impact of development, upgrade and preserve the natural habitat of endangered marine species and to establish specific zones for recreational uses consistent with the carrying capacity of the area.

To understand and further enhance the existing conservation practices in Terengganu, this study looks into the formal marine conservation efforts via MPAs, as sanctioned by the existing legal framework, and explore the traditional knowledge of the local communities via previous studies, as found in published works, to determine the possibility of enhancing these efforts. This would be able to point towards the possibility of involving the local communities, whose livelihood mainly depend on marine resources and are directly affected by the current state of marine environment, in conserving and sustainably managing the marine environment. Local knowledge is commonly understood as the long-standing traditions and practices of certain regional, indigenous, or local communities encompassing the wisdom, knowledge, and teachings of these communities (Talaat et al. 2012a). Alternatively termed as traditional knowledge, it constitutes a cumulative body of knowledge, know-how, practices, and representations maintained and developed by peoples with extended histories of interaction with the natural environment. Considered as an asset, it focuses on the use of knowledge such as traditional technical know-how, or traditional ecological, scientific or medical knowledge.

TEK is a branch of local knowledge and is defined by Berkes et al. (2000) as "a cumulative body of knowledge, practice and belief evolving by adaptive processes an handed down through generations by cultural transmission about the relationship of living beings (includin nans) with one another and with their environment as su ested by Huntington (2000), TEK refers to $\mathrm{km}$ insights acquired through extensi grvatio on and or a species that is either pa down an or adition or shared among users of resource. The lue of TEK has been increasingly ogh researchers and due to such developn, D w (1, 05) f Jer widens the scope of TEK to $b$ mo comp encompassing knowledge from a variety ctivm numited to hunting, medicinal products collect household economy and trade, and spiritual divination.

The objectives of the study are to examine the existing marine conservation efforts in Terengganu as well as to explore the possibility of factoring in the TEK of the local communities to enhance these efforts for the sustainable conservation and management of marine resources via collaborative management between the government and the community.

\section{MATERIALS AND METHODS}

The study involves investigation of the existing marine conservation efforts in the state of Terengganu, which is one of the federated states in Malaysia situated on the east coast of Peninsular Malaysia bordering the South China Sea (Figure 1). For the purpose of the study, various legal documents in Malaysia are examined namely, the Federal Constitution of Malaysia as the highest law of the land and the federal legislations namely the Fisheries Act, 1963, Fisheries (Prohibited Area) Regulations and Fisheries Act 1985 (National Parks). These domestic legal documents are complemented by international legal instruments like the Convention of Biological Diversity and the IUCN Resolutions. Apart from that, secondary data in the forms of published works in journals and web pages are also being referred to in the study.

In this library based study, a alitati method via content analysis was carried on legal cuments or instruments. In analysins data the ear tool utilised to examine these sal Doctrine of Statutory Inte ion, $m$ h is portant to have the grasp on rationa behind egal provisions contained therej Apart fron the legal documents, published schol y writinas of puevious studies were also considered to sup the scussion in this article, particularly on the or ocal communities in conserving the marine ment.

\section{RESULTS AND DISCUSSION}

\section{Divisions of power in managing the coastal and marine areas}

As provided under the Federal Constitution of Malaysia, there are divisions of power between federal and states power where the federal government is to have jurisdiction over all living and non-living resources in the estuarine and marine areas whereas the state governments' jurisdictions are over all land matters including the foreshore. Table 1 explains the distribution of powers as provided under the Malaysian Federal Constitution.

Table 1. Distribution of powers in Federal Constitution of Malaysia

\begin{tabular}{lll}
\hline Federal list & State list & Concurrent list \\
\hline Mineral resources & Land & Wildlife \\
Marine and estuarine fisheries & Agriculture & Town and country planning \\
Pest control & Forestry & National parks \\
Shipping and navigation & Infrastructure activities for state works & Rehabilitation \\
Water supplies & Water & Eroded and mined land \\
Tourism & Riverine fisheries & Drainage \\
Infrastructure activities for federal works & & Irrigation \\
& & Housing \\
\hline
\end{tabular}




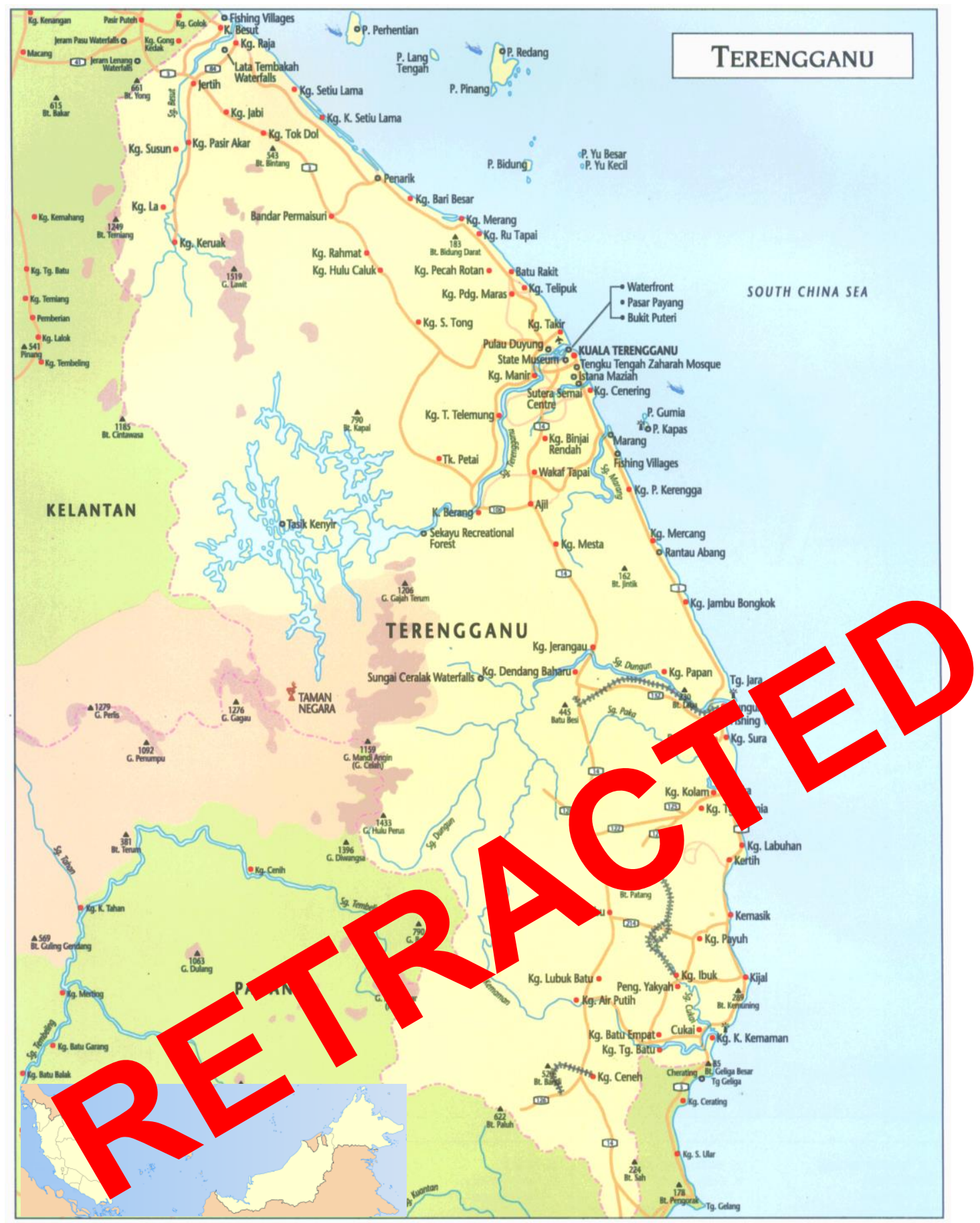

Figure 1. Study site in the state of Terengganu, the Peninsular Malaysia

\section{Marine Protected Areas in Terengganu}

In the realisation that marine fisheries resources in Malaysia are depleting and that the importance of coral reefs areas as critical habitats zone, the Fisheries (Prohibited Area) Regulations was enacted under the then Fisheries Act 1963 and Pulau Redang, Terengganu was declared as the first FPA (Talaat et al. 2013). In the Terengganu waters, the only MPAs are the islands that have been gazetted as marine parks. There are currently 13 marine parks in Terengganu which are limited to the areas surrounding the designated islands ( 2 nautical miles). Apart from the first and formerly FPA of Redang, which has now been gazetted as a marine park island, the other marine parks are the islands of Perhentian Besar, Perhentian Kecil, Kapas, Tenggol, Nyireh, Lang Tengah, Ekor Tebu, Pinang, Susu Dara, Lima, Yu Kecil and Yu Besar. The total areas of these marine park islands amount to $568.69 \mathrm{~km}^{2}$.

A marine park is an area of the sea that has been zoned as a sanctuary for the coral reef community, with its diversity of flora and fauna, is considered as possibly the 
most productive ecosystem in the world. Part IX (Section 41-45) of the Fisheries Act 1985 provides for the establishment of Marine Parks in Malaysia, which is administered by the Marine Department of Malaysia. The main purpose of establishing Marine Parks in the country is to protect, conserve and manage in perpetuity the significant representatives of marine ecosystems, particularly coral reefs and their associated flora and fauna. Marine parks or marine reserves may be gazetted to provide special protection to the aquatic flora and fauna and to protect, preserve and manage the natural breeding grounds and habitat of aquatic life particularly of the endangered species. Other objectives are to allow for natural regeneration of depleting aquatic life, to promote scientific research, to preserve and enhance the pristine state and productivity and most importantly, to regulate recreational and other activities in such areas in order to avoid irreversible damage to its environment (Talaat et al, 2103).

Coral reefs are important breeding and nursery grounds for many commercially important species of marine resources. The benefits behind the establishment of marine parks are for the protection and maintenance of marine life ecosystem and habitat, rejuvenation of over exploited zones and their maintenance for the protection of endangered species of marine organisms as well as for the establishment of zones for research and educational purposes and for recreational uses and tourism. Provisions for the establishment and management of the marine parks in the Fisheries Act 1985 (National Parks) allows for the control of certain specified activities namely underwater photography, swimming, observation and appreciation of the aquatic flora and fauna, scuba diving and snorkeling. Prohibited activities, unless with special permission, are water skiing, speed boat racing and jet skiing, destruc removal or collection of the corals and other aq tife vandalizing and structure or object within th ari anchoring of boats over the coral areas, ng and ing weapons that endanger aquatic lif ishing thin 3 . $\mathrm{m}$ radius of the park vicinity well as dis rging of pollutants and rubbish. Inoki curren situation, protecting or cons ang har reso cannot be limited to areas st oun g the arine parks alone. Since the Terenggand astan ars is vast with more than $244 \mathrm{~km}$ coastline (Toun Terengganu 2017) and fishing is inherently a major economic activity in the state, more areas should be designated as MPAs.

MPAs is an important tool for fishery management particularly to overcome overexploitation of marine resources as well as to encourage sustainable fishing. The MPAs approach has been widely implemented for the health of marine ecosystem when any illegal fishing activities were prohibited. However, the allowance for ecotourism may eventually lead to other environmental problems. As suggested by Islam et al. (2014), huge ecotourism activities at Pulau Perhentian, which may have exceeded the carrying capacity of the island, have been affecting the coral reefs and fish habitat and consequentially reduced the local fishermen catches. In the meantime, the MPAs fishing line regulation has also been found to cause pressures affecting their sustainable livelihoods.

It is important to note that although one of the objectives behind the designation of MPAs is to increase the local community's economy by conserving fish biological cycle, some of the local fisherman are still struggling to sustain their lives. For example, in the Setiu district in Terengganu, the local fishermen are still under the poverty line where their dependencies on the sea realm are high as has been passed down from generations. Although some of them are rich because of different level of knowledge, techniques and technology for fishing but most of them are still being categorized below the poor income margin or the Bottom 40 (B40) (Jarina 2014). It has been found that the existing implementation of MPAs lacks engagement with the local communities and fails to factor in their needs and interests. As argued by Sumaila (et al. 2000) and (Islam et al. 2014), management of MPAs will be botched if there is no community engagement and participation.

\section{Discussion}

Marine Protected Areas and the Local Communities

Community-based MPAs are designed both artisanal fisheries management as we as bic versity conservation (Christie and White 906, Botton ip or community-based strategies commol in ntries where the formal institut a cause of colonialism or becau gover ents not effectively serve the public or simpl ecause ck of financial and technical sources. $\mathrm{N}$ theless, community-based manageme of MPAs mayserve to be more effective $\mathrm{b}$ se res ree $\mathrm{u} s$ are being actively involved and b tu of a sense of ownership, trust and co be may build up (Christie and White 1997; Po ac 2005).

Terengganu, like the rest of the country, the existing $1 P$ As are all formally institutionalised under the Marine Parks Department, which is a federal government agency. As mentioned earlier, the gazetting of these marine parks are mostly done in tourist destination islands or as tourist attractions and it may not be wrong to point out that this top-down strategies might have not taken into account the resource users', in this case the Terengganu fishermen's knowledge, perception and understanding of their surrounding marine environment. Community-based MPAs is practically non-existent in this country and perhaps this may be the reason for lukewarm participation by the resource users in the conservation of the existing MPAs.

\section{Applying Local Knowledge in Marine Resources Conservation: A Collaborative Management}

As a branch of local knowledge related to environmental conservation, TEK is generally understood as a cumulative body of knowledge, practice and belief, evolving by adaptive processes and handed down through generations by cultural transmission that involves the relationship of mankind with their environment. As proposed by Hansen (2002), TEK is used to sustain the community and its culture and to maintain the biological 
resources necessary for the continued survival of the community. Marine TEK may therefore be defined as part of the larger body of indigenous knowledge to include a complex knowledge of the sea (i.e. reefs, lagoons and target species), livelihood activities (fishing techniques and practices, management rules), and related beliefs and legends of social and cultural values (Leopold et al. 2008).

In the uncertain and heterogeneous marine environment, the local fishermen's knowledge and skills are particularly vital in ensuring sustainable and effective livelihood (Firth 1975; Acheson 1981). Nowadays, TEK has been recognized as key in marine resources conservation efforts via sustainable use of marine biodiversity and ecosystem. This aspect of human capital, especially the TEK that fishermen possess, is increasingly being recognised by scientists who now seek their input towards a better understanding of fish ecology and local marine environments (Johannes et al. 2000). TEK plays important roles in maintaining the socio-cultural structures and baseline for most fishing regulations. Therefore, acknowledging the TEK along with the local communities' interests will assist in achieving efficient management of the fishery or marine resources.

The information and knowledge of the local fishermen as direct users has been helping many conservation efforts with their knowledge on the presence, abundance and threats of marine lives, which have become the starting points for most scientific researches to understand more and tackle the problems efficiently (Rajamani et al. 2014). Other than that, the coastal and small island communities have also been acknowledged to have wealth of knowledge to observe changes in the environment. Their deep observations and ability to monitor and observe the changes in environment through the seas, clouds, animals, plants and insects including the moon, sun and the stars helps to predict the weather forecast and most important ${ }^{1}$ the hydro-meteorological hazards (Hiwasaki et al. 20

TEK is commonly used in natural resource as a substitute for baseline environmental changes over time in remote regi that ve lit recorded scientific data (Freema ,92). In the orts to conserve marine resources, the re ans are long standing knowledge of io fis men ensuring the sustainable supply of rine sourc ough the use of sustainably traditional 119 and and practices. As proposed by Garcia-Quija (2007), TEK, which is held by groups engaging directly with their ecosystem for food production, must be increasingly recognised as a valuable tool for understanding environmental change as well as for ecosystem management and conservation. This is in line with the view proposed earlier by both Kull (2004) and Guha (2003) that the 'authoritarian biologist' ideology has in fact delayed the formal recognition that these local resource users, apart from using the resources, are also managing natural resources through various livelihood strategies employed based on their perception of status the resources.

TEK helps to provide information on folk taxonomy and systematics, population-level knowledge, and ecological relationships and eventually benefited for the conservation of biology. Since TEK is obtained through trial and error where the knowledge of local fishermen is not compatibly a set of knowledge to scientific knowledge. However, as noted by Drew (2005), the local knowledge helps scientific research by providing new hypothesis to be tested. Factoring in TEK in conservation efforts cannot be restricted to one-off extraction of information but should be considered for a long-term collaboration and development of information hence the term 'collaborative management'. The concept of collaborative management has long been accepted elsewhere as a description of variations in joint management arrangements between government and community or with the private sector stakeholders as suggested by Christie and White (1997). Inclusion of local participation from the communities and private stakeholders in marine conservation is necessary to ensure the sustainability of marine resources.

As resource users, who are going to be directly impacted by the supply fluctuation in fisheries and other marine resources, the local communities' TEK must be taken into consideration and used as baseline knowledge in collaborative management of the marine and coastal environment. In Malaysia and Terengganu in particular, the traditional knowledge held by the fishing boat skipper in locating a good place to fish can be used as a merasm to create more MPAs designated more for fir ses ro urce management rather than for tourism po Like se, the traditional fishing methods an actices lin the $y$ of 'unjam' made of biodegrad a rove also proven to be more sust e and vironm ytal friendly as compared to the more m ern ve or artificial reef such as deploye cyru.

A concerte effort by all tho takeholders including the loca mmun and e resource users must be carried out 1 esources to ensure its sustainable supp al communities must also be appreciated as epos nes or knowledge with regard to biological divers, habitats and their seasonal fluctuations. The local Is rmen's familiarity with the use of sustainable fishing methods and belief in the sustainable fishing practices are pertinent to ensure the sustainable supply of marine resources. Since the indigenous and local people have lived as part of functioning ecosystems around the world for millennia, they have long history of ecological knowledge and experience shared through generations. This knowledge should therefore be sought to help deal with our increasing social and environmental concerns due to ecosystem degradation we are facing today. Since at present, there are no existing policies, laws, rules and regulations pertaining to fishery resource management (including MPAs) that utilise traditional knowledge in Malaysia and Terengganu in particular, efforts must be made to recognise as well as utilise the roles of these local communities and their TEK in marine resources conservation (Talaat et al. 2012a,b; Talaat et al. 2013).

As a conclusion, it can be surmised that although one of the objectives behind the designation of MPAs is to increase the local communities' economy by conserving fish biological cycle, some of the local fishermen are still struggling to sustain their lives. Thus, collaborative 
management, which involves the local communities and puts values to their traditional knowledge and management systems, could be the best mechanism to sustainably conserve and manage marine resources. Increased reliance on local participation of the community as resource users will somehow guarantee certain level of their commitment to collaborate with the local government and other government agencies either in managing the marine environment or acting as watchdogs for the enforcement agencies. Sustainable conservation and management of marine resources requires a concerted effort from all the stakeholders including the local communities as both resource users and as repositories of traditional knowledge. This effort will eventually be facilitated through collaborative management involving both the government and community accountability.

\section{ACKNOWLEDGEMENTS}

Authors want to acknowledge the Malaysian Ministry of Higher Education for the Long Term Research Grant.

\section{REFERENCES}

Acheson JM. 1981. Anthropology of fishing. Ann Rev Anthropol 10: 275 316.

Berkes F, Gadgil M, Folke C. 2000. Rediscovery of Traditional Ecological Knowledge as adaptive management. Ecol Appl 10 (5): 1251-1262.

Christie P, White AT. 1997. Trends in development of coastal area management in tropical countries: from central to community orientation. Coastal Manag 25 (2): 155-181.

Christie P, White AT. 2006. Best practices in governance and enforcement of marine protected areas: an overview. FAO Expert Workshop on Marine Protected Areas and Fisheries Management: Review of Issues and Considerations (12-14 June 2006).

Drew J. 2005. Use of Traditional Ecological Knowledge in marine conservation. Conserv Biol 19 (4): 1286-1293.

Firth R. 1975. Malay Fishermen: Their Peasant Economy. 2nd ed. New York.

Freeman MMR. 1992. The nature and utility of traditi cologica Tala knowledge. Northern Perspect 20 (1): 9-12

García-Quijano CG. 2007. Fishers' knowle assemblages: Bridging between scier knowledge in southeastern Puerto Rico. Amer Anthropol 109 (3): 529-536.

Guha R. 2003. Authoritarian biologist and the arrogance of antihumanism: Wildlife conservation in the Third World. In Saberwal VK, Rangarajan M. (eds) Battles over nature: Science and the politics of conservation. Permanent Black, Delhi.

Hansen SA. 2002. Intellectual property and traditional ecological knowledge: institutionally globalized biopiracy?. Profess Ethics Rep 15 (3): 1-4.

Hiwasaki L, Luna E, Syamsidik, Shaw R. 2014. Process for integrating local and indigenous knowledge with science for hydrometeorological disaster risk reduction and climate change adaptation in coastal and small island communities. Intl $\mathbf{J}$ Dis Risk Reduct 10: 15-27

Huntington HP. 2000. Using traditional ecological knowledge in science: methods and applications. Ecol Appl 10: 1270-1274.

Islam GMdN, Yew TS, Noh KM, Noh AFM. 2014. Community's perspectives towards marine protected area in Perhentian Marine Park, Malaysia. Open J Mar Sci 4: 51-60.

IUCN. 2010. Marine Protected Areas, Why Have Them?. www.iucn.org.

Jarina MJ. 2014. The Perceptions of Poverty among Small-Scale FisherFolks in Terengganu, Malaysia. Dynamiques Internationales (9): 112.

Johannes RE, Freeman MMR, Hamilton RJ. 2000. Ignore fishers' knowledge and miss the boat. Fish Fisher 1 (3): 257-271.

Kelleher G. 1999. Guidelines for Marine Protected Areas. IUCN, Gland, Switzerland and Cambridge, UK.

Kull CA. 2004. Isle of fire: the political ecology of landscape burning in Madagascar. University of Chicago Press, Illinois.

Leopold M, Herrenschmidtb J.B, Thamanc R. 2008. The Relevance of Traditional Ecological Knowledge for Modern Management of Coral Reef Fisheries in Melanesia. Proceedings of the 11th International Coral Reef Symposium, Ft. Lauderdale, Florida, 7-11 Jul

Pollnac R, Pomeroy RS. 2005. Factors influencing the anabilit integrated coastal management projects in $\mathrm{Ph}$ pines Indonesia. Ocean Coast Manag 48: 233-25'

Rajamani L, Rodriquez-Vaga LH, Oii Knowledge of Penang's Marine L, Zuraidah MY. (eds) p ering L 1 Kn dge: Life, Science and Technoloov Penerbit Y, Pulau

Sumaila UR, Guennet der J, Ch pagdee K. 2000. Addressing ecosystem effect fishing using mar protected areas. ICES J Mar Sci 57: 752-760.

Talaat W Tahir Husai hL. 2012a. Traditional Knowledge on Gene arces arding the Cultural Sustenance of Indig us unities. Asian Soc Sci 8 (7): 184-191 t WI Musain ML. 2012b. Sustainable Management of For Biodiversity and the Present Malaysian Policy and Legal k. J Sust Dev 5 (3): 76-83.

AW, Tahir NM, Husain ML. 2013. The laws and policies for the
. The sustainable management of biodiversity in Malaysia. J Sustain Sci Manag 8 (2): 276-289.

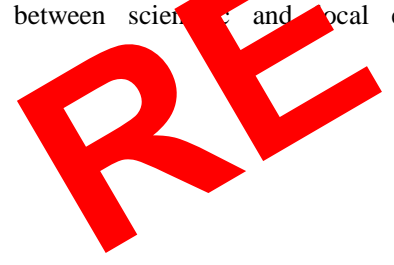

